\title{
Financial Performance and Sustainability of Moroccan Microfinance Institutions: An Empirical Study
}

\author{
Samir Aguenaou ${ }^{1}$, Sarah Allouche ${ }^{1}$, Nada El Maliki ${ }^{1} \&$ Jawad Abrache $^{1}$ \\ ${ }^{1}$ School of Business Administration, Al Akhawayn University in Ifrane, PO Box 1829, Avenue Hassan II, Ifrane, \\ 53000, Morocco \\ Correspondence: Samir Aguenaou, School of Business Administration, Al Akhawayn University in Ifrane, PO Box \\ 1829, Avenue Hassan II, Ifrane, 53000, Morocco. E-mail: s.aguenaou@aui.ma
}

Received: September 6, 2019

Accepted: October 11, 2019

Online Published: October 15, 2019

doi:10.5430/afr.v8n4p144

URL: https://doi.org/10.5430/afr.v8n4p144

\begin{abstract}
This study explores the determinants of the financial performance and sustainability of Moroccan Microfinance Institutions (MFIs). Through the use of panel data concerning 10 MFIs (available on the MIX platform) with different time frames, three OLS models are run and aim to explain MFIs financial performance and sustainability using independent variables related to the size of the MFIs, the quality of their loan portfolios, the degree of outreach, and their productivity. The results obtained show that: (1) the personnel productivity contributes significantly to the MFIs' Return on Assets and their sustainability, and (2) the loan repayment level of MFIs customers is an important determinant of their sustainability.
\end{abstract}

Keywords: Microfinance, credit, morocco, financial performance, sustainability

\section{Introduction}

For Microfinance institutions (MFIs), profitability can bear many meanings and therefore is measured along different dimensions. In its classical context, it is basically studied from the perspective of profits (revenues exceeding expenses). Measures like the Return on Assets (ROA) or Return on Equity (ROE) are then employed to capture the financial performance. Profitability can also be linked to other dimensions, longer term success dimensions, such as sustainability. As the profits of such institutions are often plowed back in the capital of the firm, higher profits are generally indicative of higher degrees of independence and better sustainability. The two perspectives are thus intertwined and this paper attempts to study them in the specific context of Moroccan MFIs.

The first Moroccan MFIs were created in 1993 by the AMSED association ("Association de Solidarite et de développement"). They were inspired by the model of the Grameem Bank, founded in the 1970s by Mohammad Yunus in Bangladesh (Robinson, 2001) and were followed by a few Moroccan civil society actors (e.g., Nourredine Ayouch with "Fondation Zakoura" in 1995, Al Karama in 1996, and Al AMANA with FONDEP in 1998; Micro finance, 2019). The funding of such MFIs was helped by USAID subsidies with an initial seed fund of 16 Million USD. In 1999, a microfinance law was enacted to regulate the microfinance activity sector. The law imposed on the associations to modify their statuses and isolate their microfinance activities into distinctive sub-units (Micro finance, 2019). To help reducing poverty nationwide, the Moroccan government started in 2000 its financial support to the sector with an initial subsidy of 100 Million of Moroccan Dirhams (MAD) (i.e. 10.5 Million dollars) through Hassan II fund. This support enabled the originally small MFIs to enlarge their customer base and increase the amounts of granted loans. As a result, the loan portfolios of MFIs have been multiplied by 11 and their client base by 4 between 2003 and 2007. In 2008, the crisis has weakened the sector leading to a movement of the microcredit victims in 2011 ("les victimes du micro-crédit") (Aziki, 2016). Various legal frameworks were established in a bid to regulate the MFI market during the 2012-2015 times frame, in relation notably to the nature of their financial products and their relation to commercial companies.

As of March 2019, there are 13 Moroccan MFIs operating in the Kingdom (FNAM, 2019), with 84\% of the market share concentrated among three leading MFIs. The latest survey data available (2015) indicated an MFI client base of more than 1 million active borrowers, $64 \%$ of which are women, as well as a 3:2 ratio of urban borrowers to rural ones (FinDev, 2019). 
In Morocco's socio-economic context, the role played by MFIs in the efforts to reduce poverty and glaring social disparities is crucial. Indeed, they target population in need of capital to embark in revenue generating economic activities, but with very little chances to secure such financing through loans from the traditional banking sector. They are also supposed to assist their clients in their quest of business success by providing council and assistance in routine tasks such as development of business plans, basic financial planning and management, etc. A healthy relationship with the clients as business partners, is key for MFIs to establish a win-win environment.

Yet, the two aspects of the MFIs' role (financial efficiency and social impact and outreach) are still very often contrasted and seen as contradictory and offsetting each other. In the specific context of Morocco, we have observed that the sustainability dimension of Moroccan MFIs has been totally overlooked by current research, with focus on profitability as the main dimension of financial performance. This is normal given that the sector is relatively new and immature. This paper is an attempt to close this gap and explore the tradeoff between the two dimensions.

This paper investigates the determinants of the financial performance and sustainability of Moroccan Microfinance Institutions (MFIs). Three models are run using panel data of 10 MFIs, and aim to explain MFIs financial performance - proxied by Return on Equity (ROE) and Return on Assets (ROA) and sustainability - proxied by Operational Self-sufficiency (OSS) using the following dimensions: Portfolio at Risk (PAR), size of the MFI, outreach and productivity. The main findings are that the personnel productivity contributes significantly to the MFIs' ROA and their OSS. Moreover, the study reveals that the quality of the MFIs' portfolios (in other terms the loan repayment level of their customers) impacts their sustainability.

The paper is organized as follows. In Section 2, we present a brief survey of the literature on models for the assessment of financial performance and sustainability of MFIs, and state more precisely our contribution. In Section 3 we state the study's hypotheses and variables, and the models investigated. Section 4 discusses the data and the methodology of the study. Section 5 presents the results obtained and their analysis, along with limitations of the study. Finally, Section 6 summarizes our contribution and suggests avenues for further research.

\section{Literature Review}

Several statistical approaches have been adopted to measure MFIs performance, and to relate its purely financial dimensions to their primary social role, which is to give access to credit to the needy. The most common of these approaches is indeed panel data analysis, more specifically: panel OLS regression, pooled OLS, and random and fixed effect models (e.g., Khan et al., 2017; Borjesson \& Hulten, 2016; Patil \& Gopal, 2015; Cull et al., 2007; Ibrahim et al., 2016). Another group of studies use non-parametric and semi-parametric techniques such as Data Envelopment Analysis (DEA) and Stochastic Frontier Analysis (SFA) to benchmark MFIs and/or establish associations between their outreach and their efficiency (e.g., Paxton, 2007; Keita, 2007)

The statistical studies differ in terms of the dependent variables used as proxies to MFI performance. A first group of studies use ROE (Return on Equity) and/or ROA (Return on Assets) (e.g., Patil \& Gopal, 2015; El Kharti, 2014; Borjesson \& Hulten, 2016; Ibrahim et al., 2016). Khan \& Butt (2017) and Sekabira (2013) use a Financial Self-Sufficiency (FSS) factor in the form of the ratio of total operating revenue before taxes minus the grants, to the total operating expenses. Janda \& Turbat, (2013) measure the performance through the yield, proxied by returns from loans granted to customers, while Assefa, Hermes \& Meesters (2013) use the Lerner Index, a price cost index. The range of explanatory variables used include:

- The size of the MFI proxied by the total assets of the institution (e.g., Bassem, 2009; Khan \& Butt, 2017; Borejesson \& Hulten, 2016; Assefa, Hermes \& Meesters; 2013) or by the number of outstanding/active borrowers (Janda \& Turbat, 2013; El Kharti, 2014; Sekabira, 2013; Assefa, Hermes \& Meesters, 2013).

- $\quad$ The age of the MFI (Bassem, 2009; El Kharti, 2014; Assefa, Hermes \& Meesters, 2013).

- Various risk factors such as risk coverage ratio and the capital structure (Fersi \& Boujelbéne, 2015).

- Staff productivity and dependency ratio (Kinde, 2012).

- Various macroeconomic factors such as inflation, income per capita (Ibrahim et al., 2016).

The existence of a tradeoff between the financial and social dimensions of MFIs is a question that continues to divide the community of researchers. While the early literature generally acknowledges a tradeoff between profitability and depth of outreach, relatively newer contributions provide more contrasted findings. For instance, Navajas et al. (2000) and Cull et al. (2007) condition the tradeoff to the wealth of the borrowers. Kipesha \& Xianzhi (2013) use a panel of 47 MFIs in several East-African countries to establish that the stakeholder's perspective matters: while institutional 
stakeholders tend to consider that more profitable MFIs serve better the poor, beneficiaries generally perceive a tradeoff.

Several works investigate the relationship between outreach of MFIs and their sustainability. For instance, Patil \& Gopal (2015) use a balanced panel of 17 MFIs and a financial ratio approach to establish a tradeoff between outreach and sustainability. Paxton \& Cuevas (2002) argue that greater levels of outreach decrease MFI efficiency due to a higher weight of unit transaction costs. In contrast, the existence of tradeoff is refuted in the studies by Paxton (2003), Quayes (2011) and Quayes (2015), among others.

A deeper investigation of the various dimensions of outreach (depth, breadth, length, and scope) and their interactions can be found in the study by Schreiner (2002). Other proxies of social impact, such as the proportion of minorities or special sub-social groups in the pool of MFIs' customers, are studied by Kneiding \& Tracey (2009).

Corporate governance practices have also tremendously contributed to the enhancement of MFIs' performance. However, less evidence has been provided about how these governance characteristics can serve the needy people both in a financial and sustainable manner. Van Damme et al. (2016) use the ensuing four corporate governance variables to assess MFIs performance in the context of Sri Lanka: the number of board members, the number of women on board, the CEO/chair duality and the presence of a women CEO. Results show that the smaller the board and the higher the proportion of women in it the more financially efficient is the MFI. The study also confirms that $\mathrm{CEO} /$ Chair duality as well as the presence of a woman CEO is negatively influencing the outreach efficiency.

Gohar and Batool (2015) investigate the effect of corporate governance on the financial performance of 25 MFIs in Pakistan for the period 2005-09. Contrary to Van Damme et al's findings, Gohar and Batool (2015) show that the presence of a woman CEO influences positively the outreach efficiency.

The effect of Corporate social responsibility (CSR) on firm performance has been recently investigated by many authors (e.g., Li et al., 2018; Sun, 2012; Bogan, 2012).

Li et al. (2018) confirm that the CSR activities of companies as well as their sustainability are starting to be a big concern to stakeholders. The authors assert that "The market seems inefficient initially in processing nonfinancial information such as CSR but is "willing to learn"” ( $\mathrm{Li}$ et al. 2018). They also confirm that a resilient social performance enhances the firm's reputation at least in the short term.

A review of 291 MFIs in 34 Sub-Saharan African countries was done by Chikalipah (2017). The author examines the effect of the institutional environment on the performance of these MFIs. A combination of OLS with fixed effects and a Generalized Method of Moments (GMM) approach is used in the study and establishes that MFIs performance is positively impacted by the institutional environment. The latter includes elements such as: business freedom, level of corruption, investment and labor freedom, and property rights. The findings of the study argue in favor of a strong institutional environment as a prerequisite for strong and sustainable MFIs performance.

MFIs' performance in the Moroccan context has received comparatively little attention in the literature. To the best of our knowledge, the only published study on Moroccan MFIs is that of El Kharti (2014). The latter uses a panel data analysis to relate the MFIs financial performance to specific determinants such as MFIs age, quality of portfolio, share of equity in total assets, staff productivity and the percentage of female borrowers. Our paper expands the scope of research on MFI performance in the Moroccan context beyond financial performance and social impact and considers sustainability as an important indicator for the MFIs survival and operational effectiveness. Moreover, the panel data used (19 years, up to 2017) updates and expands the data set used by El Kharti (2014).

\section{Hypotheses and Models}

This study analyzes the performance of Moroccan MFIs considering financial performance and sustainability in relation to the following variables: the MFI's portfolio quality (Portfolio at Risk (PAR)), the size of the MFI (Gross Loan Portfolio), the MFI's outreach (Breadth of Outreach), and MFI's personnel productivity.

\subsection{Assumptions}

The study hypothesizes that profitability and sustainability are positively related to the size of the MFI and productivity variables (Borjesson, Hulten, 2016). On the other hand, the study assumes a negative relationship with portfolio quality and productivity considering the literature's proven claim on the existence of a financial-social outreach tradeoff (Patil \& Gopal, 2015; Kneiding \& Tracey; 2008). The study also assumes a negative relationship with portfolio quality, represented in this paper by Portfolio at Risk (PAR) variable. 


\subsection{Dependent Variables}

The dependent variables used by our models are defined accordingly:

Profitability

The MFI's financial performance is represented by the two most common variables in the literature: return on assets (ROA) and return on equity (ROE) (El Kharti, 2014; Wanjiru, 2016). ROA measures both the profitability and how efficient is the MFI in using its assets (Hartarska, 2005; El Kharti, 2014). ROA captures profitability (profit margin included) irrespective of the financing model used by the MFI. ROE (return on equity), on the other hand, shows how profitable are the subsidiaries, grant-providers or donating organizations to such MFIs. ROA and ROE are thus complementary in building a clear picture of financial performance, especially considering the fact that Moroccan MFIs rely heavily on external funding and subsidiaries (El Kharti, 2014, p.31-32).

ROA $=$ Net operating Income $/$ Total assets.

$\mathrm{ROE}=$ Net Income / Equity.

Sustainability

Sustainability is defined in the literature as the ability of MFIs to cover their costs while being able to reinvest their profit to grow and become independent from grants and donations (International Organizations, governments) and rely on their own generated funds (Bassem, 2009; Hartarska, 2005). Operational Self-Sufficiency (OSS) is the variable most commonly used to measure sustainability, as it explicitly measures an MFI's ability to balance operating costs (excluding financial costs) and revenues (Khan \& Butt, 2017).

Operational Self-Sufficiency (OSS) $(\%)=$ Operating revenues $/$ Operating Expenses.

\subsection{Independent Variables}

The choice of our independent variables follows the parametric framework of the literature review, specifically the studies by El Kharti (2014), Borjesson \& Hulten (2016), Patil \& Gopal (2015), Kneiden \& Tracey (2009), and Bassem (2009).

\section{Portfolio at Risk (PAR)}

PAR measures the part of the portfolio that is impacted by debt default as a percentage of the total portfolio (Inter-American, 2003). Following El Kharti (2014), PAR 30 was used instead of PAR 90.

PAR $30=$ Outstanding balance of unpaid loans / Total outstanding loan balance.

Size of MFI

As suggested by the corporate finance literature, firm size can be measured using different proxies such as market capitalization, total sales and total assets (Dang et al., 2018). Nonetheless, our choice of the total outstanding balance of loans, or Gross Loan Portfolio (GLP) for the specific case of MFI follows the approach of most recent contributions (e.g., Patil \& Gopal, 2015).

GLP $=$ Outstanding balance of loans excluding Interest to be received.

Outreach

The MFI's breadth of outreach helps measure whether or not an MFI has fulfilled its social duty towards the bank-marginalized pool of the population (Kneiden \& Tracey, 2009).

Breadth of outreach $=$ Number of Active Borrowers (NAB) (Khan \& Butt, 2017; Patil \& Gopal, 2015).

Personnel Productivity

Personnel productivity is considered through staff member and loan officer underlying ratios:

Loans per staff member (Wanjiru, 2016).

Loans per loan officer and borrowers per loan officer (Patil \& Gopal, 2015).

The dependent and independent variables used by our models are summarized in Tables 1 and 2. More precise definitions of the variables are presented in Tables 3 and 4 . 
Table 1. Dependent Variables Summary Table

\begin{tabular}{cc}
\hline Dimension Measured & Variable \\
\hline Profitability & Return on Assets (ROA) \\
& Return on Equity (ROE) \\
Sustainability & Operational Self-sufficiency (OSS) \\
\hline
\end{tabular}

Table 2. Independent Variables Summary Table

\begin{tabular}{cc}
\hline Dimension Measured & Variable \\
\hline Portfolio quality & Portfolio at Risk (PAR) \\
Size of MFI & Gross loan Portfolio (GLP) \\
Productivity & Personnel Productivity \\
& Loans per staff member. \\
& Loan Officers Productivity \\
Outreach & Loans per loan officer. \\
& Borrowers per loan officer. \\
\end{tabular}

Table 3. Definitions of Dependent Variables

\begin{tabular}{cc}
\hline Dependent Variable & Definition \\
\hline ROA & Net operating Income - Taxes / Average \\
ROE & Total Assets \\
OSS & Net Operating Income - Taxes / Average \\
& Total Equity \\
& $\begin{array}{c}\text { Financial Revenue / Financial Expense+ Net } \\
\text { Impairment Loss+ Operating Expense }\end{array}$
\end{tabular}

Table 4. Definitions of Independent Variables

\begin{tabular}{cc}
\hline Independent Variable & Definition \\
PAR & $\begin{array}{c}\text { Outstanding balance of unpaid loans / Total } \\
\text { Outstanding loan balance. } \\
\text { BLO }\end{array}$ \\
LSM & $\begin{array}{c}\text { Outstang balance of loans excluding } \\
\text { Interest to be received } \\
\text { Number of Active Borrowers / Number of } \\
\text { Loan officers. }\end{array}$ \\
LLO & $\begin{array}{c}\text { Number of Loans Outstanding / Number of } \\
\text { Personnel. }\end{array}$ \\
BREADTH & $\begin{array}{c}\text { Number of Loans outstanding / Number of } \\
\text { Loan Officers. }\end{array}$ \\
\end{tabular}

\section{4 Models}

Three OLS models, each one using a single dependent variable among the ones suggested for performance and sustainability measurement, are accordingly considered:

Model A: ROA as dependent variable.

$\mathrm{ROA}=\beta 1(\mathrm{PAR})+\beta 2(\mathrm{GLP})+\beta 3(\mathrm{BLO})+\beta 4(\mathrm{LSM})+\beta 5(\mathrm{LLO})+\beta 6(\mathrm{BREADTH})+\varepsilon$.

Model B: ROE as dependent variable.

$$
\mathrm{ROE}=\beta 1(\mathrm{PAR})+\beta 2(\mathrm{GLP})+\beta 3(\mathrm{BLO})+\beta 4(\mathrm{LSM})+\beta 5(\mathrm{LLO})+\beta 6(\mathrm{BREADTH})+\varepsilon .
$$

Model C: Operational Self-sufficiency (OSS) as dependent variable.

$$
\mathrm{OSS}=\beta 1(\mathrm{PAR})+\beta 2(\mathrm{GLP})+\beta 3(\mathrm{BLO})+\beta 4(\mathrm{LSM})+\beta 5(\mathrm{LLO})+\beta 6(\mathrm{BREADTH})+\varepsilon .
$$


The following hypotheses are made:

$\mathrm{H}_{1}$ : ROA, ROE and OSS are positively related to GLP.

$\mathrm{H}_{2}$ : ROA, ROE and OSS are positively related to productivity.

$\mathrm{H}_{2-\mathrm{a}}$ : ROA, ROE and OSS are positively related to borrowers per loan officer.

$\mathrm{H}_{2-\mathrm{b}}$ : ROA, ROE and OSS are positively related to loans per staff member.

$\mathrm{H}_{2-\mathrm{c}}$ : ROA, ROE and OSS are positively related to loans per loan officer.

$\mathrm{H}_{3}$ : ROA, ROE and OSS are negatively related to PAR.

$\mathrm{H}_{4}$ : ROA, ROE and OSS are negatively related to breadth of outreach.

\section{Data and Methodology}

Panel data about 11 Moroccan microfinance institutions is collected from the MIX online database (themix.org, 2019). The time frames of the data vary between 19 years and 3 years of data observations, as indicated by Table 5 .

Table 5. MFI Data summary (source: themix, 2019)

\begin{tabular}{ccc}
\hline MFI Name & $\begin{array}{c}\text { Number of observations per } \\
\text { variable }\end{array}$ & Dates \\
\hline Al Amana & 19 & $1999-2017$ \\
Al Karama & 15 & $2003-2017$ \\
Attadamoune & 18 & $2000-2017$ \\
Fondation Al Baraka & 17 & $2001-2017$ \\
INMAA & 15 & $2003-2017$ \\
AIMC & 3 & $2009-2011$ \\
AMOS & 11 & $2002-2012$ \\
ARDI & 8 & $2003-2010$ \\
Attawfiq Micro-Finance & 15 & $2002-2016$ \\
Izdihar Micro-finance & 7 & $2003-2009$ \\
Zakoura & 12 & $1999-2010$ \\
\hline
\end{tabular}

The data collected has been analyzed using a panel data analysis on STATA. Following clean-up and adjustment based on preliminary diagnosis tests, the three models are run under the fixed-effect model. Given its relatively small number of observations available, AMIC is considered as an outlier and removed.

\section{Results and Analysis}

Preliminary analysis of this panel data, through the Hausman test (see Appendix 1), resulted in adopting the fixed effect model as a basis to our statistical analysis. The panel data itself has been adjusted as a result of other common diagnostic tests (heteroscedasticity, multicollinearity, normality). Multicollinearity issues have been encountered and fixed by deleting the LLO and BLO variables, while heteroscedasticity has been tackled through a log transformation of the ROA and ROE dependent variables.

The fixed effect model is then run for models A, B, and C. The findings are summarized as follows (see Appendix 2 for more detailed results).

Model A - ROA: Significant Model - F-test $<0.05$ with a probability of 0.0046.

Table 6. Significance Summary Results of Model A

\begin{tabular}{cccc}
\hline Variable & Coefficients & $t$ & Prob $>|t|$ \\
\hline GLP & $3.74 \mathrm{e}-08$ & 1.43 & 0.161 \\
PAR & -29.89921 & -1.87 & 0.069 \\
BREADTH & -.0000016 & -1.21 & 0.236 \\
LSM & .0136782 & 2.26 & 0.028 \\
\hline
\end{tabular}

As far as ROA is concerned, Table 6 shows that the only significant explanatory variable is LSM, the Loans per Staff Member. This is in line with El Kharti's research premise (El Kharti, 2014) that ROA is not only a measure of 
profitability but also of efficiency of the use of the MFI's assets. Some of the other variables, while being statistically non-significant in their relation to ROA, still display some correlation with the latter (see Appendix 3). This is the case in particular of GLP (0.2408) and BREADTH (0.255), mirroring similar correlation findings in previous studies, El Kharti (2014), Patil \& Gopal, (2015), and Bassem (2009).

Model B - ROE: Significant Model - F-test $<0.05$ with a probability 0.0293.

Table 7. Significance Summary Results of Model B

\begin{tabular}{cccc}
\hline Variable & Coefficients & $t$ & Prob $>|t|$ \\
\hline GLP & $6.15 \mathrm{e}-08$ & 2.81 & 0.008 \\
PAR & -25.57019 & -1.71 & 0.096 \\
BREADTH & -.00000214 & -2.30 & 0.027 \\
LSM & .0060895 & 1.28 & 0.210 \\
\hline
\end{tabular}

Concerning ROE, Table 7 indicates that BREADTH and GLP are the significant explanatory variables. These results are in line with the findings of El Kharti (2014) where productivity ratios (LSM in this study) had no significant influence on ROE. In contrast, El Kharti (2014) finds that ROE is explained by the lack of maturity of Moroccan MFIs and the lack of efficiency of loan officers. A possible explanation of this could be the more recent data used in our study versus El Kharti's, and an assumed increase in the productivity following the increase in the maturity of the MFIs. Our GLP and BREADTH results also agree with the findings in Jayantih Patil (2015)'s study on 17 rural MFIs in India.

Model C - OSS: Significant Model - F-test $<0.05$ with a probability 0.000 .

Table 8. Significance Summary Results of Model C

\begin{tabular}{ccccc}
\hline Variable & Coefficients & $t$ & $P>|t|$ \\
\hline GLP & $1.12 \mathrm{e}-09$ & 0.39 & 0.699 \\
PAR & -1.804556 & -2.08 & 0.042 \\
LSM & $-8.97 \mathrm{e}-07$ & & -0.68 & 0.500
\end{tabular}

Finally, Table 8 indicates that the Portfolio at Risk (PAR) and the Loans per Staff Member (LSM) are the significant explanatory variables for the OSS. The PAR finding seems to indicate that repayment rate influences the sustainability of the MFIs, in the sense that the higher the unpaid loans ratio, the less sustainable the MFI. In this regard, our study joins similar findings in other contexts (for instance Khan \& Butt, 2017). On the other hand, the fact that LSM impacts significantly the MFI's sustainability contrasts with the findings in Patil \& Gopal's (2015) study, where it turns out to be statistically insignificant. The differences in the economic and financial environments, as well as in the regulatory frameworks between Morocco and India are a plausible explanation of these contrasted results.

\section{Concluding Remarks}

This paper aims at exploring the determinants of financial performance and sustainability of Moroccan MFIs. Following a literature review where the emphasis is put on traditional profitability metrics such as ROA and ROE, the paper provides a more complete understanding of the factors driving the continuing success of MFIs in the Moroccan context. Our study establishes the significant impact of staff productivity on ROA. Another important finding is the negative impact of the number of active borrowers on ROE. Finally, the study shows that the quality of the portfolio (measured through the Portfolio at Risk metric) and staff productivity impact the sustainability of MFIs.

The main limitation of the study lies in the nature of the data collected. Even though the data set used was exhaustive in terms of time scope and number of MFIs (10 out of the 13 available in the Moroccan market), the data is still unbalanced in certain variables and for certain MFIs. Furthermore, the data had to go through several rounds of manipulations following the results of the diagnostic tests. Access to data of better quality would certainly yield more reliable and robust results.

The variability of the findings from one study to the other could partially be explained by endogeneity problems and the complex web of causality relations that govern MFIs performance, sustainability, and social impact, and their 
explanatory variables. Econometric techniques have been suggested to alleviate the endogeneity issues (Li, 2016). These techniques include the use of a combination of GMM dynamic models, instrumental variables, fixed effect models, lagged independent variables, and additional control variables. The adaptation of these techniques to the topic of our study (Moroccan MFIs performance, sustainability, and outreach) will be the subject of our next research endeavor.

Another limitation of the study is the use of simple OLS panel analysis. By using this type of approach and analysis, we have been successful in revealing important relationships involving various metrics related to financial performance and sustainability, social impact, and staff productivity. Yet, more sophisticated statistical approaches are likely to provide further findings and an even deeper understandings of the MFI dynamics in Morocco. Among the possible techniques we are considering for our next research on the topic, Structural Equation Modeling (SEM) can be singled out. Another potential avenue to explore is the combination of Data-Envelopment Analysis (DEA) non-parametric techniques with parametric, regression-based analysis.

\section{References}

Assefa, E., Hermes, N. \& Meesters, A. (2013). Competition and the performance of microfinance institutions. Applied Financial Economics, 23(9), 767-782. https://doi.org/10.1080/09603107.2012.754541

Bassem, B. S. (2009). Governance and performance of microfinance institutions in Mediterranean countries. Journal of Business Economics and Management, 10(1), 31-43. https://doi.org/10.3846/1611-1699.2009.10.31-43

Bogan, V. L. (2012). Capital structure and sustainability: An Empirical Study of Microfinance Institutions. Review of Economics and Statistics, 94(4), 1045-1058. https://doi.org/10.1162/REST_a_00223

Borjesson, J. \& Hultén, A. (2016). Determinants of profitability in microfinance institutions in Sub-Saharan Africa. Bachelor Thesis, University of Gothenburg, School of Business, Economics and Law.

Chikalipah, S. (2017). Institutional environment and microfinance performance in Sub - Saharan Africa. African Development Review, 29(1), 16-27. https://doi.org/10.1111/1467-8268.12235

Cull, R., Demirgüç - Kunt, A. \& Morduch, J. (2007). Financial performance and Outreach: A global analysis of $\begin{array}{llll}\text { leading microbanks. The Economic } & \text { Journal, }\end{array}$ F107-F133. https://doi.org/10.1111/j.1468-0297.2007.02017.x

Dang, C., Li, Z. \& Yang, C. (2014). Measuring Firm Size in Empirical Corporate Finance. Journal of Banking \& Finance, Elsevier, 86(C), 159-176. https://doi.org/10.1016/j.jbankfin.2017.09.006

El Kharti, L. (2014). The determinants of financial performance of microfinance institutions in Morocco: a panel data analysis. Savings and Development, 38(1), 27-44.

Fersi, M. \& Boujelbéne, M. (2016). The determinants of the performance and the sustainability of conventional and $\begin{array}{llll}\text { Islamic microfinance } & \text { institutions. Economics }\end{array}$ https://doi.org/10.17265/2328-7144/2016.05.001

FinDev Maroc. (2019). Retrieved from https://www.findevgateway.org/fr/pays/maroc.

Gohar, R. \& Batool, A. (2015). Effect of corporate governance on performance of microfinance institutions: A case from Pakistan. Emerging Markets Finance and Trade, 51(S6), S94-S106. https://doi.org/10.1080/1540496X.2015.1080559

Hartarska, V. (2005). Governance and performance of microfinance organizations in Central and Eastern Europe and the newly independent states, World Development, $33(10), \quad$ 1627-1643. https://doi.org/10.1016/j.worlddev.2005.06.001

Ibrahim, S. N., Kamaruddin, N. I. \& Daud, S. (2016). Assessing the Determinants of Profitability Performance on Islamic Microfinance in Malaysia. Journal of Economics, Business and Management, 4(3), 201-205. https://doi.org/10.7763/JOEBM.2016.V4.391

Janda, K. \& Turbat, B. (2013). Determinants of the financial performance of microfinance institutions in Central Asia. Post-Communist Economies, 25(4), 558-569. https://doi.org/10.1080/14631377.2013.844935

Jayanthi, P., (2015). Performance Analysis Through Ratio Analysis of Microfinance Institutions of Karnataka, India. International Journal of Research in Commerce \& Management, 6(1), 1-6.

Keita, M. (2007). Efficacité relative des institutions de microfinance : une application de la méthode DEA. Ph.D. Thesis, Université du Québec à Montréal. 
Khan, Z. A., Butt, S. \& Khan, A. A. (2017). Determinants of Financial Self Sufficiency in Microfinance Institutions: A study of Pakistan, India and Bangladesh. European Online Journal of Natural and Social Sciences, 6(2), 296-301.

Kinde, B. A. (2012). Financial sustainability of microfinance institutions (MFIs) in Ethiopia. European Journal of Business and Management, 4(15), 1-10.

Kipesha, E. \& Xianzhi, Z. (2013). Sustainability, Profitability and Outreach Tradeoffs: Evidences from Microfinance Institutions in East Africa. European Journal of Business and Management, 5(8), 136-148.

Kneiding, C. \& Tracey, P. (2008). Towards a Performance measurement framework for Community Development Finance Institutions in the UK. Journal of Business Ethics, 86(3), 327-345. https://doi.org/10.1007/s10551-008-9850-9

Li, Z. F. (2016). Endogeneity in CEO Power: A survey and experiment. Investment Analysts Journal, 45(3), 149-162. https://doi.org/10.1080/10293523.2016.1151985

Li, Z. F., Minor, D., Wang, J. \& Yu, C. (2018). A Learning Curve of the Market: Chasing Alpha of Socially Responsible Firms. SSRN Electronic Journal. https://doi.org/10.2139/ssrn.3224796

Navajas, S., Schreiner, M., Meyer, R. L., Gonzalez-vega, C. \& Rodriguez-meza, J. (2000). Microcredit and the poorest of the poor: Theory and evidence from Bolivia. World Development, 28(2), 333-346. https://doi.org/10.1016/S0305-750X(99)00121-7

Patil, J. \& Gopal, K. (2015). Performance analysis through ratio analysis of Microfinance Institutions of Karnataka. International Journal of research in Commerce and management, 6(1), 1-6.

Paxton, J. (2003). A poverty outreach index and its application to microfinance. Economics Bulletin, 9, 1-10.

Paxton, J. (2007). Technical efficiency in a semi-formal financial sector: The case of Mexico. Oxford Bulletin of Economics and Statistics, 69(1), 57-74. https://doi.org/10.1111/j.1468-0084.2007.00466.x

Paxton, J. \& Cuevas, C. (2002). Outreach and sustainability of member-based rural financial intermediaries. In The Triangle of Microfinance: Financial Sustainability, Outreach, and Impact, Edited by: Zeller, M. and Meyer, R. 135-151. Baltimore and London: Johns Hopkins University Press.

Quayes, S. (2011). Depth of outreach and financial sustainability of microfinance institutions. Applied Economics, 44(26), 3421-3433. https://doi.org/10.1080/00036846.2011.577016

Quayes, S. (2015). Outreach and performance of microfinance institutions: a panel analysis. Applied Economics, 47(18), 1909-1925. https://doi.org/10.1080/00036846.2014.1002891

Robinson, M. S., Fidler, P. J. (2001). The microfinance revolution: sustainable finance for the poor. Washington DC; World Bank. https://doi.org/10.1596/0-8213-4524-9

Schreiner, M. (2002). Aspects of outreach: A framework for discussion of the social benefits of microfinance. Journal of International Development, 14(5), 591-603. https://doi.org/10.1002/jid.908

Sun, L. (2012). Further evidence on the association between corporate social responsibility and financial performance. International Journal of Law and Management, 54(6), 472-484. https://doi.org/10.1108/17542431211281954

themix.org (2019). The Mix Online Database. Retrieved May 4, 2019, from https://www.themix.org.

Van Damme, P., Wijesiri, M. \& Meoli, M. (2016). Governance and efficiency of microfinance institutions: empirical evidence from Sri Lanka. South Asia Economic Journal, 17(2), 236-247. https://doi.org/10.1177/1391561416650102

Wanjiru, K. (2016). Microfinance Institutions in Kenya: A Mission Drift or Progression? Bachelor Thesis, Strathmore University, Strathmore Institute of Mathematical Sciences. 


\section{Appendices}

\section{Appendix 1 - Hausman Tests Results}

\begin{tabular}{|c|c|c|c|c|}
\hline & \multicolumn{2}{|c|}{ W Coofeicient: } & \multirow{3}{*}{$\begin{array}{c}\text { (b-B) } \\
\text { Difference }\end{array}$} & \multirow{3}{*}{$\begin{array}{c}\| q=t\left(d_{i a d}\left(V_{-} b-V_{-} B\right)\right. \\
\text { B.z. }\end{array}$} \\
\hline & (b) & (B) & & \\
\hline & Fixed & Random $\pi$ & & \\
\hline GramuLanbua & $1.23 \mathrm{se}-10$ & $2.10=-10$ & $-8.68=-11$ & $3.75=-11$ \\
\hline Doxtellioara & -.6126505 & -.3868119 & -.2258386 & .0510633 \\
\hline Numberotac-s & $-1.11 e-07$ & $-2,38 e-07$ & $1.27 e-07$ & 4. $62 e-08$ \\
\hline Dorrower mp & 0007934 & .0006549 & ooo13as & . \\
\hline Loanuper $=10 n=$ & -.0005264 & -.0004413 & -.000085 & . \\
\hline Loanapexat $\sim x$ & 0004554 & .0005399 & -0000845 & . \\
\hline
\end{tabular}
B = ineonaigent under Ha, erfielent under Ho, obtalned from roreg

Tent: Moz difterence in gooftiolentm not mytematic

$\operatorname{ch} 12(A)=(b-B) \cdot\left[\left(V_{-} b-V_{-} B\right)-(-1)\right](b-B)$

Drabrahtz- $\quad 16.92$

Drabreh12 - 0.0021

(V_b-V_B is not posivive definite)

Figure 1. Hausman Test for Model A

\begin{tabular}{l|rrrr} 
& $\begin{array}{c}\text { (b) } \\
\text { fixedC }\end{array}$ & $\begin{array}{c}\text { RandomC } \\
\text { Raficients }\end{array}$ & $\begin{array}{c}(\mathrm{b}-\mathrm{B}) \\
\text { Difference }\end{array}$ & $\begin{array}{r}\text { sqrt (diag(V_b-V_B }) \\
\text { S.Z. }\end{array}$ \\
\hline GrosgLoanP o & $-4.62 \mathrm{e}-10$ & $1.10 \mathrm{e}-09$ & $-1.56 \mathrm{e}-09$ & $3.80 \mathrm{e}-10$ \\
Portfolioa s & -1.913924 & -1.317607 & -.5963172 & .2986119 \\
Numberofac s & $-2.62 \mathrm{e}-07$ & $-1.36 \mathrm{e}-06$ & $1.10 \mathrm{e}-06$ & $3.62 \mathrm{e}-07$ \\
Borrowergp r & .0016929 & .0021297 & -.0004368 &. \\
Loansperlo r & -.0006468 & -.0015069 & .0008601 &. \\
Loanspergt r & .0021698 & .0030644 & -.0008947 & .0002532 \\
\hline
\end{tabular}

$\mathrm{b}=$ consistent under Ho and $\mathrm{Ha}$; obtained from xtreg $B=$ inconsistent under Ha, efficient under Ho; obtained from xtreg

Test: Ho: difference in coefficients not systematic

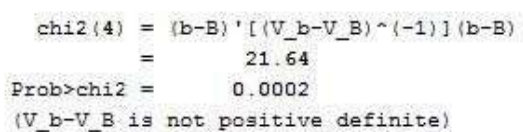

Figure 2. Hausman Test for Model B

\begin{tabular}{|c|c|c|c|c|}
\hline & \multicolumn{2}{|c|}{ Coefficients -} & \multirow{3}{*}{$\begin{array}{c}(\mathrm{b}-\mathrm{B}) \\
\text { Difference }\end{array}$} & \multirow{3}{*}{$\begin{array}{c}\left.\text { sqrt (diag }\left(V_{-} b-V_{-} B\right)\right) \\
\text { S.z. }\end{array}$} \\
\hline & (b) & (B) & & \\
\hline & FixedB & RandomB & & \\
\hline GrossLoanP o & $1.94 \mathrm{e}-09$ & $2.26 e-09$ & $-3.18 e-10$ & 1. $44 e-09$ \\
\hline Portfolioa s & -11.01662 & -7.17756 & -3.839064 & .88233 \\
\hline Numberofac s & $-7.36 e-07$ & $-1.41 e-06$ & $6.74 e-07$ & $1.23 e-06$ \\
\hline Borrowersp r & -.0038637 & -.0004911 & -.0033726 & .0029522 \\
\hline Loansperlonx & .0054645 & .0014817 & .0039828 & .0027587 \\
\hline Loansperst $x$ & -.0017828 & -.0005011 & -.0012816 & .0011727 \\
\hline
\end{tabular}

$b=$ consistent under Ho and Ha; obtained from xtreg $B=$ inconsistent under Ha, efficient under Ho; obtained from xtreg

Test: Ho: difference in coefficients not systematic

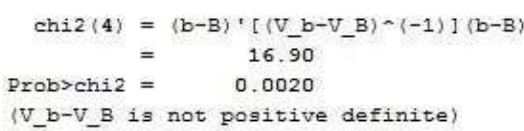

Figure 3. Hausman Test for Model C 


\section{Appendix 2 - Fixed-effects After Adjustment Model Results}

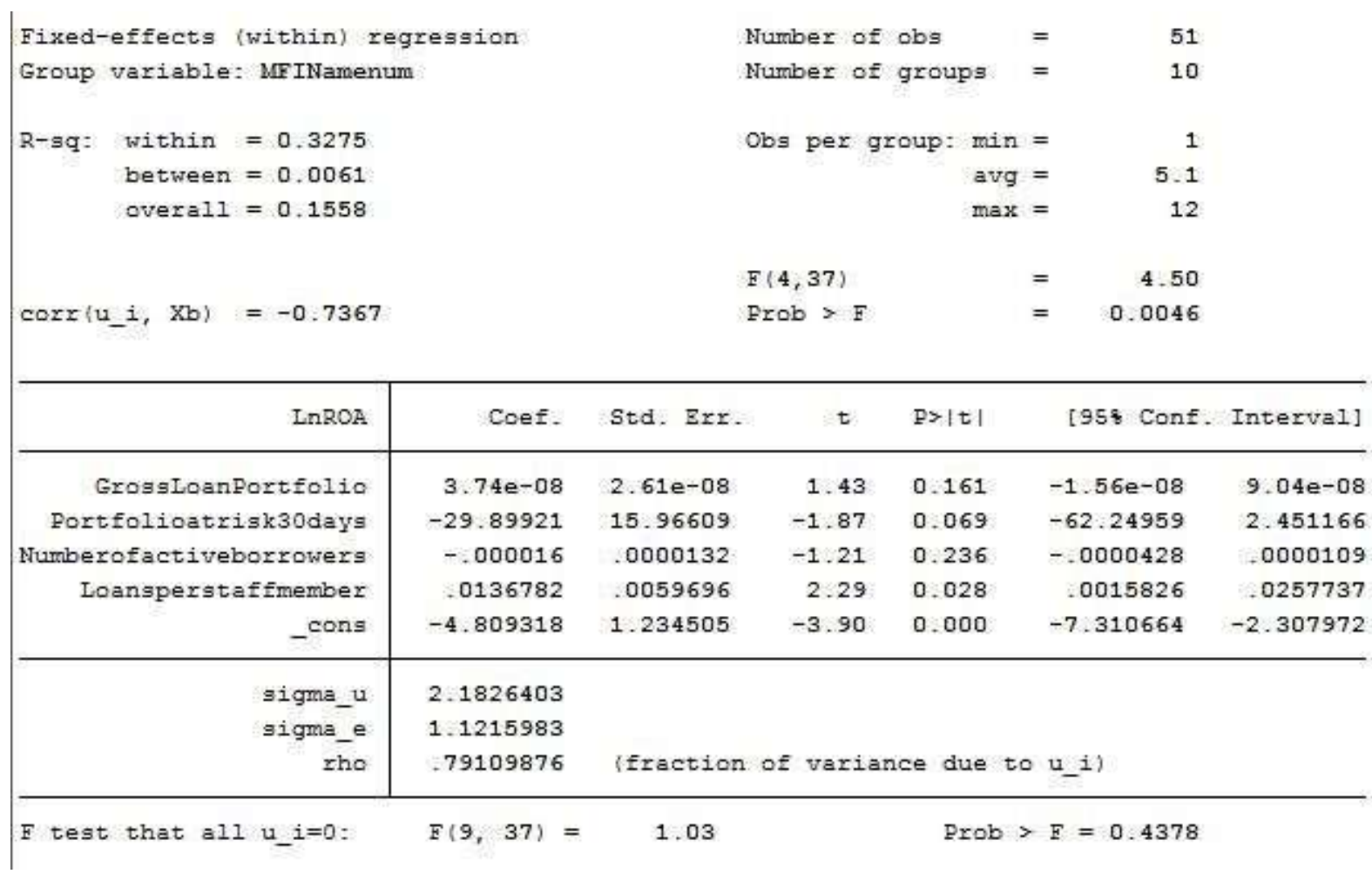

Figure 4. Fixed-effects Model A

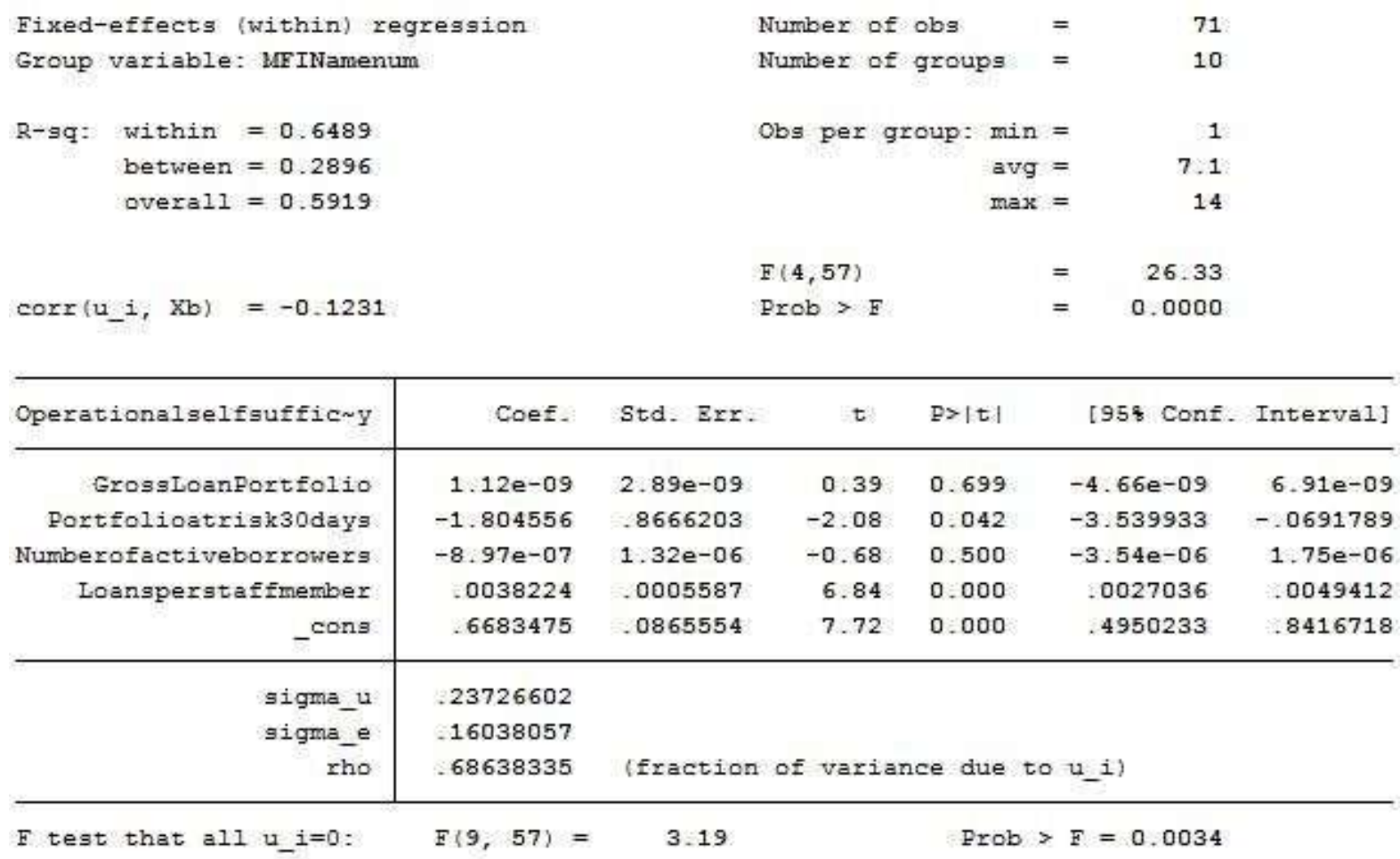

Figure 5. Fixed-effects Model B 


\section{Appendix 3 - Correlation Matrices}

\begin{tabular}{|c|c|c|c|c|c|}
\hline & InROA & GrossL $\sim 0$ & Portfon & Number $\sim s$ & Loan ber \\
\hline InROA & 1. 0000 & & & & \\
\hline GrossLoanP o & 0.2408 & 1.0000 & & & \\
\hline Portfolioa s & -0.1977 & -0.1921 & 1.0000 & & \\
\hline Numberofac s & 0.2555 & 0.8592 & -0.2483 & 1.0000 & \\
\hline Loansperst $\sim$ r & 0.4814 & 0.4411 & -0.4767 & 0.6867 & 1.0000 \\
\hline
\end{tabular}

Figure 7. Correlation Matrix, Model A

\begin{tabular}{r|rrrrr} 
& LnROE GrossL $\sim 0$ Portfons Number s Loan ber \\
\hline LnROE & 1.0000 & & & & \\
GrossLoanP o & 0.3034 & 1.0000 & & & \\
Portfolioa s & -0.1134 & -0.1795 & 1.0000 & & \\
Numberofac $\sim 5$ & 0.2899 & 0.8608 & -0.2337 & 1.0000 & \\
Loansperst r & 0.2731 & 0.4453 & -0.4021 & 0.6756 & 1.0000
\end{tabular}

Figure 8. Correlation Matrix, Model B

\begin{tabular}{|l|rrrrr} 
& Operat y & GrossL o Portfors Number s Loan ber \\
\hline Operationa y & 1.0000 & & & & \\
GrossLoanP o & 0.2840 & 1.0000 & & & \\
Portfolioa s & -0.4615 & -0.0896 & 1.0000 & & \\
Numberofac s & 0.3070 & 0.8720 & -0.1521 & 1.0000 & \\
Loansperst r & 0.7276 & 0.4426 & -0.4508 & 0.6529 & 1.0000
\end{tabular}

Figure 9. Correlation Matrix, Model C 